\title{
Parathyroid hormone receptors in GtoPdb v.2021.3
}

Alessandro Bisello ${ }^{1}$, Michael Chorev $^{2}$, Peter A. Friedman ${ }^{1}$, Tom Gardella ${ }^{3}$, Rebecca Hills ${ }^{4}$, Harald Jueppner $^{3}$, T. John Martin ${ }^{5}$, Robert A. Nissenson ${ }^{6}$, John Thomas Potts, Jr. ${ }^{3}$, Caroline Silve ${ }^{7}$, Ted B. Usdin $^{8}$ and Jean-Pierre Vilardaga ${ }^{1}$

1. University of Pittsburgh, USA

2. Harvard Medical School, USA

3. Massachusetts General Hospital, USA

4. University of Edinburgh, UK

5. University of Melbourne, Australia

6. University of California San Francisco, USA

7. INSERM, France

8. National Institute of Mental Health, USA

\begin{abstract}
The parathyroid hormone receptors (nomenclature as agreed by the NC-IUPHAR Subcommittee on Parathyroid Hormone Receptors [49]) are class B G protein-coupled receptors. The parathyroid hormone (PTH)/parathyroid hormone-related peptide (PTHrP) receptor (PTH1 receptor) is activated by precursor-derived peptides: PTH ( 84 amino acids), and PTHrP (141 amino-acids) and related peptides (PTH-(1-34), PTHrP-(1-36)). The parathyroid hormone 2 receptor (PTH2 receptor) is activated by the precursor-derived peptide TIP39 (39 amino acids). [ $\left.{ }^{125} \mathrm{I}\right] \mathrm{PTH}$ may be used to label both PTH1 and PTH2 receptors. The structure of a long-active PTH analogue (LA-PTH, an hybrid of PTH-(1-13) and PTHrP-(14-36)) bound to the PTH1 receptor- $\mathrm{G}_{\mathrm{S}}$ complex has been resolved by cryoelectron microscopy [147]. Another structure of a PTH-(1-34) analog bound to a thermostabilized inactive PTH1 receptor has been obtained with X-ray crytallography [34].
\end{abstract}

\section{Contents}

This is a citation summary for Parathyroid hormone receptors in the Guide to Pharmacology database (GtoPdb). It exists purely as an adjunct to the database to facilitate the recognition of citations to and from the database by citation analyzers. Readers will almost certainly want to visit the relevant sections of the database which are given here under database links.

GtoPdb is an expert-driven guide to pharmacological targets and the substances that act on them. GtoPdb is a reference work which is most usefully represented as an on-line database. As in any publication this work should be appropriately cited, and the papers it cites should also be recognized. This document provides a citation for the relevant parts of the database, and also provides a reference list for the research cited by those parts. For further details see [13].

Please note that the database version for the citations given in GtoPdb are to the most recent preceding version in which the family or its subfamilies and targets were substantially changed. The links below are to the current version. If you need to consult the cited version, rather than the most recent version, please contact the GtoPdb curators.

\section{Database links}

Parathyroid hormone receptors

https://www.guidetopharmacology.org/GRAC/FamilyDisplayForward?familyId=53

Introduction to Parathyroid hormone receptors

https://www.guidetopharmacology.org/GRAC/FamilyIntroductionForward?familyId=53

Receptors

PTH1 receptor

https://www.guidetopharmacology.org/GRAC/ObjectDisplayForward?objectId=331 
PTH2 receptor

https://www.guidetopharmacology.org/GRAC/ObjectDisplayForward?objectId=332

\section{References}

1. Abou-Samra AB, Jüppner H, Force T, Freeman MW, Kong XF, Schipani E, Urena P, Richards J, Bonventre JV and Potts Jr JT et al.. (1992) Expression cloning of a common receptor for parathyroid hormone and parathyroid hormone-related peptide from rat osteoblast-like cells: a single receptor stimulates intracellular accumulation of both cAMP and inositol trisphosphates and increases intracellular free calcium. Proc Natl Acad Sci USA 89: 2732-6 [PMID:1313566]

2. Abou-Samra AB, Jüppner H, Khalifa A, Karga H, Kong XF, Schiffer-Alberts D, Xie LY and Segre GV. (1993) Parathyroid hormone (PTH) stimulates adrenocorticotropin release in AtT-20 cells stably expressing a common receptor for PTH and PTH-related peptide. Endocrinology 132 : 801-5 [PMID:7678801]

3. Alonso V, Ardura JA, Wang B, Sneddon WB and Friedman PA. (2011) A naturally occurring isoform inhibits parathyroid hormone receptor trafficking and signaling. J Bone Miner Res 26: 143-55 [PMID:20578167]

4. Amizuka N, Henderson JE, White JH, Karaplis AC, Goltzman D, Sasaki T and Ozawa H. (2000) Recent studies on the biological action of parathyroid hormone (PTH)-related peptide (PTHrP) and PTH/PTHrP receptor in cartilage and bone. Histol Histopathol 15: 957-70 [PMID:10963138]

5. Augustine M and Horwitz MJ. (2013) Parathyroid hormone and parathyroid hormone-related protein analogs as therapies for osteoporosis. Curr Osteoporos Rep 11: 400-6 [PMID:24078470]

6. Barrett MG, Belinsky GS and Tashjian Jr AH. (1997) A new action of parathyroid hormone. receptor-mediated stimulation of extracellular acidification in human osteoblast-like SaOS-2 cells. J Biol Chem 272: 26346-53 [PMID:9334207]

7. Bastepe M, Raas-Rothschild A, Silver J, Weissman I, Wientroub S, Jüppner H and Gillis D. (2004) A form of Jansen's metaphyseal chondrodysplasia with limited metabolic and skeletal abnormalities is caused by a novel activating parathyroid hormone (PTH)/PTH-related peptide receptor mutation. J Clin Endocrinol Metab 89: 3595-600 [PMID:15240651]

8. Behar V, Nakamoto C, Greenberg Z, Bisello A, Suva LJ, Rosenblatt M and Chorev M. (1996) Histidine at position 5 is the specificity "switch" between two parathyroid hormone receptor subtypes. Endocrinology 137: 4217-24 [PMID:8828480]

9. Behar V, Pines M, Nakamoto C, Greenberg Z, Bisello A, Stueckle SM, Bessalle R, Usdin TB, Chorev M, Rosenblatt M and Suva LJ. (1996) The human PTH2 receptor: binding and signal transduction properties of the stably expressed recombinant receptor. Endocrinology 137: 2748-2757 [PMID:8770894]

10. Bergwitz C, Jusseaume SA, Luck MD, Jüppner H and Gardella TJ. (1997) Residues in the membrane-spanning and extracellular loop regions of the parathyroid hormone (PTH)-2 receptor determine signaling selectivity for PTH and PTH-related peptide. J Biol Chem 272: 28861-8 [PMID:9360953]

11. Bisello A, Nakamoto C, Rosenblatt M and Chorev M. (1997) Mono- and bicyclic analogs of parathyroid hormone-related protein. 1. Synthesis and biological studies. Biochemistry 36: 3293-9 [PMID:9116007]

12. Bounoutas GS, Tawfeek H, Fröhlich LF, Chung UI and Abou-Samra AB. (2006) Impact of impaired receptor internalization on calcium homeostasis in knock-in mice expressing a phosphorylation-deficient parathyroid hormone (PTH)/PTH-related peptide receptor. Endocrinology 147: 4674-9 [PMID:16840548]

13. Buneman P, Christie G, Davies JA, Dimitrellou R, Harding SD, Pawson AJ, Sharman JL and Wu Y. (2020) Why data citation isn't working, and what to do about it Database 2020 [PMID:32367113]

14. Calvi LM, Sims NA, Hunzelman JL, Knight MC, Giovannetti A, Saxton JM, Kronenberg HM, Baron R and Schipani E. (2001) Activated parathyroid hormone/parathyroid hormone-related protein receptor in osteoblastic cells differentially affects cortical and trabecular bone. J Clin Invest 107: 277-86 [PMID:11160151]

15. Carter PH, Jüppner H and Gardella TJ. (1999) Studies of the N-terminal region of a parathyroid hormone-related peptide (1-36) analog: receptor subtype-selective agonists, antagonists, and photochemical cross-linking agents. Endocrinology 140: 4972-81 [PMID:10537121]

16. Carter PH, Liu RQ, Foster WR, Tamasi JA, Tebben AJ, Favata M, Staal A, Cvijic ME, French MH and Dell V et al.. (2007) Discovery of a small molecule antagonist of the parathyroid hormone receptor by using an N-terminal parathyroid hormone peptide probe. Proc Natl Acad Sci USA 104: 6846-51 [PMID:17428923]

17. Castro M, Nikolaev VO, Palm D, Lohse MJ and Vilardaga JP. (2005) Turn-on switch in parathyroid hormone receptor by a two-step parathyroid hormone binding mechanism. Proc Natl Acad Sci USA 102: 16084-9 [PMID:16236727]

18. Clark JA, Bonner TI, Kim AS and Usdin TB. (1998) Multiple regions of ligand discrimination 
revealed by analysis of chimeric parathyroid hormone 2 (PTH2) and PTH/PTH-related peptide (PTHrP) receptors. Mol Endocrinol 12: 193-206 [PMID:9482662]

19. Coutellier L, Logemann A, Kuo J, Rusnak M and Usdin TB. (2011) TIP39 modulates effects of novelty-induced arousal on memory. Genes Brain Behav 10: 90-9 [PMID:20796031]

20. Couvineau A, Wouters V, Bertrand G, Rouyer C, Gérard B, Boon LM, Grandchamp B, Vikkula M and Silve C. (2008) PTHR1 mutations associated with Ollier disease result in receptor loss of function. Hum Mol Genet 17: 2766-75 [PMID:18559376]

21. Cservenák M, Bodnár I, Usdin TB, Palkovits M, Nagy GM and Dobolyi A. (2010) Tuberoinfundibular peptide of 39 residues is activated during lactation and participates in the suckling-induced prolactin release in rat. Endocrinology 151: 5830-40 [PMID:20861230]

22. Dean T, Linglart A, Mahon MJ, Bastepe M, Jüppner H, Potts JT and Gardella TJ. (2006) Mechanisms of ligand binding to the parathyroid hormone (PTH)/PTH-related protein receptor: selectivity of a modified PTH(1-15) radioligand for GalphaS-coupled receptor conformations. Mol Endocrinol 20: 931-43 [PMID:16339275]

23. Decker E, Stellzig-Eisenhauer A, Fiebig BS, Rau C, Kress W, Saar K, Rüschendorf F, Hubner N, Grimm T and Weber BH. (2008) PTHR1 loss-of-function mutations in familial, nonsyndromic primary failure of tooth eruption. Am J Hum Genet 83: 781-6 [PMID:19061984]

24. Diamond AG, Gonterman RM, Anderson AL, Menon K, Offutt CD, Weaver CH, Philbrick WM and Foley J. (2006) Parathyroid hormone hormone-related protein and the PTH receptor regulate angiogenesis of the skin. J Invest Dermatol 126: 2127-34 [PMID:16675960]

25. Dimitrov E and Usdin TB. (2010) Tuberoinfundibular peptide of 39 residues modulates the mouse hypothalamic-pituitary-adrenal axis via paraventricular glutamatergic neurons. J Comp Neurol 518: 4375-94 [PMID:20853513]

26. Dimitrov EL, Kim YY and Usdin TB. (2011) Regulation of hypothalamic signaling by tuberoinfundibular peptide of 39 residues is critical for the response to cold: a novel peptidergic mechanism of thermoregulation. J Neurosci 31: 18166-79 [PMID:22159128]

27. Dimitrov EL, Petrus E and Usdin TB. (2010) Tuberoinfundibular peptide of 39 residues (TIP39) signaling modulates acute and tonic nociception. Exp Neurol 226: 68-83 [PMID:20696160]

28. Dobolyi A, Irwin S, Wang J and Usdin TB. (2006) The distribution and neurochemistry of the parathyroid hormone 2 receptor in the rat hypothalamus. Neurochem Res 31: 227-36 [PMID:16570212]

29. Dobolyi A, Palkovits M and Usdin TB. (2010) The TIP39-PTH2 receptor system: unique peptidergic cell groups in the brainstem and their interactions with central regulatory mechanisms. Prog Neurobiol 90: 29-59 [PMID:19857544]

30. Dobolyi A, Ueda H, Uchida H, Palkovits M and Usdin TB. (2002) Anatomical and physiological evidence for involvement of tuberoinfundibular peptide of 39 residues in nociception. Proc Natl Acad Sci USA 99: 1651-6 [PMID:11818570]

31. Dresner-Pollak R, Yang QM, Behar V, Nakamoto C, Chorev M and Rosenblatt M. (1996) Evaluation in vivo of a potent parathyroid hormone antagonist: [Nle8,18,D-Trp12,Tyr34]bPTH(734)NH2. J Bone Miner Res 11: 1061-5 [PMID:8854241]

32. Duchatelet S, Ostergaard E, Cortes D, Lemainque A and Julier C. (2005) Recessive mutations in PTHR1 cause contrasting skeletal dysplasias in Eiken and Blomstrand syndromes. Hum Mol Genet 14: 1-5 [PMID:15525660]

33. Eggenberger M, Flühmann B, Muff R, Lauber M, Lichtensteiger W, Hunziker W, Fischer JA and Born W. (1996) Structure of a parathyroid hormone/parathyroid hormone-related peptide receptor of the human cerebellum and functional expression in human neuroblastoma SK-N-MC cells. Brain Res Mol Brain Res 36: 127-36 [PMID:9011748]

34. Ehrenmann J, Schöppe J, Klenk C, Rappas M, Kummer L, Doré AS and Plückthun A. (2018) Highresolution crystal structure of parathyroid hormone 1 receptor in complex with a peptide agonist. Nat Struct Mol Biol 25: 1086-1092 [PMID:30455434]

35. Eichinger A, Fiaschi-Taesch N, Massfelder T, Fritsch S, Barthelmebs M and Helwig JJ. (2002) Transcript expression of the tuberoinfundibular peptide (TIP)39/PTH2 receptor system and nonPTH1 receptor-mediated tonic effects of TIP39 and other PTH2 receptor ligands in renal vessels. Endocrinology 143: 3036-43 [PMID:12130570]

36. Endlich N, Nobiling R, Kriz W and Endlich K. (2001) Expression and signaling of parathyroid hormone-related protein in cultured podocytes. Exp Nephrol 9: 436-43 [PMID:11702004]

37. Esbrit P, Benítez-Verguizas J, de Miguel F, Valín A and García-Ocaña A. (2000) Characterization of parathyroid hormone/parathyroid hormone-related protein receptor and signaling in hypercalcemic Walker 256 tumor cells. J Endocrinol 166: 11-20 [PMID:10856878]

38. Faber CA, Dobolyi A, Sleeman M and Usdin TB. (2007) Distribution of tuberoinfundibular peptide of 39 residues and its receptor, parathyroid hormone 2 receptor, in the mouse brain. $J$ Comp Neurol 502: 563-83 [PMID:17394159]

39. Fegley DB, Holmes A, Riordan T, Faber CA, Weiss JR, Ma S, Batkai S, Pacher P, Dobolyi A and Murphy A et al.. (2008) Increased fear- and stress-related anxiety-like behavior in mice lacking tuberoinfundibular peptide of 39 residues. Genes Brain Behav 7: 933-42 [PMID:18700839] 
40. Feinstein TN, Wehbi VL, Ardura JA, Wheeler DS, Ferrandon S, Gardella TJ and Vilardaga JP. (2011) Retromer terminates the generation of cAMP by internalized PTH receptors. Nat Chem Biol 7: 278-84 [PMID:21445058]

41. Fermor B and Skerry TM. (1995) PTH/PTHrP receptor expression on osteoblasts and osteocytes but not resorbing bone surfaces in growing rats. J Bone Miner Res 10: 1935-43 [PMID:8619374]

42. Ferrandon S, Feinstein TN, Castro M, Wang B, Bouley R, Potts JT, Gardella TJ and Vilardaga JP. (2009) Sustained cyclic AMP production by parathyroid hormone receptor endocytosis. Nat Chem Biol 5: 734-42 [PMID:19701185]

43. Frazier-Bowers SA, Simmons D, Wright JT, Proffit WR and Ackerman JL. (2010) Primary failure of eruption and PTH1R: the importance of a genetic diagnosis for orthodontic treatment planning. Am J Orthod Dentofacial Orthop 137: 160.e1-7; discussion 160-1 [PMID:20152661]

44. Gardella TJ and Jüppner H. (2001) Molecular properties of the PTH/PTHrP receptor. Trends Endocrinol Metab 12: 210-7 [PMID:11397646]

45. Gardella TJ, Jüppner H, Wilson AK, Keutmann HT, Abou-Samra AB, Segre GV, Bringhurst FR, Potts Jr JT, Nussbaum SR and Kronenberg HM. (1994) Determinants of [Arg2]PTH-(1-34) binding and signaling in the transmembrane region of the parathyroid hormone receptor. Endocrinology 135: 1186-94 [PMID:8070362]

46. Gardella TJ, Luck MD, Fan MH and Lee C. (1996) Transmembrane residues of the parathyroid hormone (PTH)/PTH-related peptide receptor that specifically affect binding and signaling by agonist ligands. J Biol Chem 271: 12820-5 [PMID:8662729]

47. Gardella TJ, Luck MD, Jensen GS, Usdin TB and Jüppner H. (1996) Converting parathyroid hormone-related peptide (PTHrP) into a potent PTH-2 receptor agonist. J Biol Chem 271: 1988893 [PMID:8702701]

48. Gardella TJ, Luck MD, Wilson AK, Keutmann HT, Nussbaum SR, Potts Jr JT and Kronenberg HM. (1995) Parathyroid hormone (PTH)-PTH-related peptide hybrid peptides reveal functional interactions between the 1-14 and 15-34 domains of the ligand. J Biol Chem 270: 6584-8 [PMID:7896796]

49. Gardella TJ and Vilardaga JP. (2015) International Union of Basic and Clinical Pharmacology. XCIII. The Parathyroid Hormone Receptors-Family B G Protein-Coupled Receptors. Pharmacol Rev 67: 310-37 [PMID:25713287]

50. Gelbert L, Schipani E, Jüppner H, Abou-Samra AB, Segre GV, Naylor S, Drabkin H and Heath H. (1994) Chromosomal localization of the parathyroid hormone/parathyroid hormone-related protein receptor gene to human chromosome 3p21.1-p24.2. J Clin Endocrinol Metab 79: 10461048 [PMID:7962272]

51. Gensure RC, Gardella TJ and Jüppner H. (2005) Parathyroid hormone and parathyroid hormonerelated peptide, and their receptors. Biochem Biophys Res Commun 328: 666-78 [PMID:15694400]

52. Gessi M, Monego G, Lauriola L, Maggiano N and Ranelletti FO. (2005) Parathyroid hormonerelated peptide (hPTHrP) and parathyroid hormone-related peptide receptor type 1 (PTHR1) expression in human thymus. J Histochem Cytochem 53: 955-62 [PMID:15879577]

53. Gesty-Palmer D, Chen M, Reiter E, Ahn S, Nelson CD, Wang S, Eckhardt AE, Cowan CL, Spurney RF and Luttrell LM et al.. (2006) Distinct beta-arrestin- and G protein-dependent pathways for parathyroid hormone receptor-stimulated ERK1/2 activation. J Biol Chem 281: 10856-64 [PMID:16492667]

54. Gidon A, Al-Bataineh MM, Jean-Alphonse FG, Stevenson HP, Watanabe T, Louet C, Khatri A, Calero G, Pastor-Soler NM and Gardella TJ et al.. (2014) Endosomal GPCR signaling turned off by negative feedback actions of PKA and v-ATPase. Nat Chem Biol 10: 707-9 [PMID:25064832]

55. Goold CP, Usdin TB and Hoare SR. (2001) Regions in rat and human parathyroid hormone (PTH) 2 receptors controlling receptor interaction with $\mathrm{PTH}$ and with antagonist ligands. J Pharmacol Exp Ther 299: 678-90 [PMID:11602681]

56. Guo J, Iida-Klein A, Huang X, Abou-Samra AB, Segre GV and Bringhurst FR. (1995) Parathyroid hormone (PTH)/PTH-related peptide receptor density modulates activation of phospholipase C and phosphate transport by PTH in LLC-PK1 cells. Endocrinology 136: 3884-91 [PMID:7649096]

57. Heise GA, Hrabrich B, Lilie NL and Martin RA. (1975) Scopolamine effects on delayed spatial alternation in the rat. Pharmacol Biochem Behav 3: 993-1002 [PMID:1223909]

58. Hoare SR, Bonner TI and Usdin TB. (1999) Comparison of rat and human parathyroid hormone 2 (PTH2) receptor activation: PTH is a low potency partial agonist at the rat PTH2 receptor. Endocrinology 140: 4419-4425 [PMID:10499494]

59. Hoare SR, Clark JA and Usdin TB. (2000) Molecular determinants of tuberoinfundibular peptide of 39 residues (TIP39) selectivity for the parathyroid hormone-2 (PTH2) receptor. N-terminal truncation of TIP39 reverses PTH2 receptor/PTH1 receptor binding selectivity. J Biol Chem 275 : 27274-83 [PMID:10854439]

60. Hoare SR, de Vries G and Usdin TB. (1999) Measurement of agonist and antagonist ligandbinding parameters at the human parathyroid hormone type 1 receptor: evaluation of receptor states and modulation by guanine nucleotide. J Pharmacol Exp Ther 289: 1323-33 
[PMID:10336523]

61. Hoare SR, Gardella TJ and Usdin TB. (2001) Evaluating the signal transduction mechanism of the parathyroid hormone 1 receptor. Effect of receptor-G-protein interaction on the ligand binding mechanism and receptor conformation. J Biol Chem 276: 7741-53 [PMID:11108715]

62. Hoare SR and Usdin TB. (2000) Tuberoinfundibular peptide (7-39) [TIP(7-39)], a novel, selective, high-affinity antagonist for the parathyroid hormone-1 receptor with no detectable agonist activity. J Pharmacol Exp Ther 295: 761-70 [PMID:11046116]

63. Hoare SR and Usdin TB. (2000) The discrepancy between the binding affinity of PTH (1-34) and RS 66271 is explained by interaction of the PTH/PTHrP receptor with G-protein. J Bone Miner Res 15: 605-8 [PMID:10750577]

64. Hoare SR and Usdin TB. (2001) Molecular mechanisms of ligand recognition by parathyroid hormone 1 (PTH1) and PTH2 receptors. Curr Pharm Des 7: 689-713 [PMID:11375776]

65. Hoare SR and Usdin TB. (1999) Quantitative cell membrane-based radioligand binding assays for parathyroid hormone receptors. J Pharmacol Toxicol Methods 41: 83-90 [PMID:10598679]

66. Hoogendam J, Farih-Sips H, Wynaendts LC, Löwik CW, Wit JM and Karperien M. (2006) Novel mutations in the PTHR1 causing Blomstrand osteochondrodysplasia type I and II. J Clin Endocrinol Metab: - [PMID:17164305]

67. Hopyan S, Gokgoz N, Poon R, Gensure RC, Yu C, Cole WG, Bell RS, Jüppner H, Andrulis IL and Wunder JS et al.. (2002) A mutant PTH/PTHrP type I receptor in enchondromatosis. Nat Genet 30: 306-10 [PMID:11850620]

68. Iida-Klein A, Guo J, Takemura M, Drake MT, Potts Jr JT, Abou-Samra A, Bringhurst FR and Segre GV. (1997) Mutations in the second cytoplasmic loop of the rat parathyroid hormone (PTH)/PTHrelated protein receptor result in selective loss of PTH-stimulated phospholipase C activity. $J$ Biol Chem 272: 6882-9 [PMID:9054374]

69. Jobert AS, Leroy C, Butlen D and Silve C. (1997) Parathyroid hormone-induced calcium release from intracellular stores in a human kidney cell line in the absence of stimulation of cyclic adenosine 3',5'-monophosphate production. Endocrinology 138: 5282-92 [PMID:9389512]

70. Jobert AS, Zhang P, Couvineau A, Bonaventure J, Roume J, Le Merrer M and Silve C. (1998) Absence of functional receptors for parathyroid hormone and parathyroid hormone-related peptide in Blomstrand chondrodysplasia. J Clin Invest 102: 34-40 [PMID:9649554]

71. Jonsson KB, John MR, Gensure RC, Gardella TJ and Jüppner H. (2001) Tuberoinfundibular peptide 39 binds to the parathyroid hormone (PTH)/PTH-related peptide receptor, but functions as an antagonist. Endocrinology 142: 704-9 [PMID:11159842]

72. Jüppner H, Abou-Samra AB, Freeman M, Kong XF, Schipani E, Richards J, Kolakowski Jr LF, Hock J, Potts Jr JT and Kronenberg HM et al.. (1991) A G protein-linked receptor for parathyroid hormone and parathyroid hormone-related peptide. Science 254: 1024-6 [PMID:1658941]

73. Kanzawa M, Sugimoto T, Kobayashi T, Kobayashi A and Chihara K. (2000) Association between parathyroid hormone (PTH)/PTH-related peptide receptor gene polymorphism and the extent of bone mass reduction in primary hyperparathyroidism. Horm Metab Res 32: 355-8 [PMID:11014383]

74. Karaplis AC, He B, Nguyen MT, Young ID, Semeraro D, Ozawa H and Amizuka N. (1998) Inactivating mutation in the human parathyroid hormone receptor type 1 gene in Blomstrand chondrodysplasia. Endocrinology 139: 5255-8 [PMID:9832466]

75. Karperien M, van der Harten HJ, van Schooten R, Farih-Sips H, den Hollander NS, Kneppers SL, Nijweide P, Papapoulos SE and Löwik CW. (1999) A frame-shift mutation in the type I parathyroid hormone (PTH)/PTH-related peptide receptor causing Blomstrand lethal osteochondrodysplasia. J Clin Endocrinol Metab 84: 3713-3720 [PMID:10523019]

76. Kronenberg HM, Lanske B, Kovacs CS, Chung UI, Lee K, Segre GV, Schipani E and Jüppner H. (1998) Functional analysis of the PTH/PTHrP network of ligands and receptors. Recent Prog Horm Res 53: 283-301 [PMID:9769712]

77. Kuo J and Usdin TB. (2007) Development of a rat parathyroid hormone 2 receptor antagonist. Peptides 28: 887-92 [PMID:17207559]

78. LaBuda CJ, Dobolyi A and Usdin TB. (2004) Tuberoinfundibular peptide of 39 residues produces anxiolytic and antidepressant actions. Neuroreport 15: 881-5 [PMID:15073536]

79. Langub MC, Monier-Faugere MC, Qi Q, Geng Z, Koszewski NJ and Malluche HH. (2001) Parathyroid hormone/parathyroid hormone-related peptide type 1 receptor in human bone. $J$ Bone Miner Res 16: 448-56 [PMID:11277262]

80. Lanske B, Karaplis AC, Lee K, Luz A, Vortkamp A, Pirro A, Karperien M, Defize LH, Ho C and Mulligan RC et al.. (1996) PTH/PTHrP receptor in early development and Indian hedgehogregulated bone growth. Science 273: 663-6 [PMID:8662561]

81. Lossdörfer S, Götz W, Rath-Deschner B and Jäger A. (2006) Parathyroid hormone(1-34) mediates proliferative and apoptotic signaling in human periodontal ligament cells in vitro via protein kinase C-dependent and protein kinase A-dependent pathways. Cell Tissue Res 325: 469-79 [PMID:16670921]

82. Mahon MJ, Donowitz M, Yun CC and Segre GV. (2002) Na(+)/H(+ ) exchanger regulatory factor 
2 directs parathyroid hormone 1 receptor signalling. Nature 417: 858-61 [PMID:12075354]

83. Maretto S, Mammi S, Bissacco E, Peggion E, Bisello A, Rosenblatt M, Chorev M and Mierke DF. (1997) Mono- and bicyclic analogs of parathyroid hormone-related protein. 2. Conformational analysis of antagonists by CD, NMR, and distance geometry calculations. Biochemistry 36: 3300-7 [PMID:9116008]

84. McCuaig KA, Clarke JC and White JH. (1994) Molecular cloning of the gene encoding the mouse parathyroid hormone/parathyroid hormone-related peptide receptor. Proc Natl Acad Sci USA 91: 5051-5 [PMID:8197183]

85. McDonald IM, Austin C, Buck IM, Dunstone DJ, Gaffen J, Griffin E, Harper EA, Hull RA, Kalindjian SB and Linney ID et al.. (2007) Discovery and characterization of novel, potent, nonpeptide parathyroid hormone-1 receptor antagonists. J Med Chem 50: 4789-92 [PMID:17850061]

86. Meulenbelt I, Min JL, van Duijn CM, Kloppenburg M, Breedveld FC and Slagboom PE. (2006) Strong linkage on 2q33.3 to familial early-onset generalized osteoarthritis and a consideration of two positional candidate genes. Eur J Hum Genet 14: 1280-7 [PMID:16912703]

87. Mierke DF, Maretto S, Schievano E, DeLuca D, Bisello A, Mammi S, Rosenblatt M, Peggion E and Chorev M. (1997) Conformational studies of mono- and bicyclic parathyroid hormonerelated protein-derived agonists. Biochemistry 36: 10372-83 [PMID:9265617]

88. Minagawa M, Yasuda T, Watanabe T, Minamitani K, Takahashi Y, Goltzman D, White JH, Hendy GN and Kohno Y. (2002) Association between AAAG repeat polymorphism in the P3 promoter of the human parathyroid hormone (PTH)/PTH-related peptide receptor gene and adult height, urinary pyridinoline excretion, and promoter activity. J Clin Endocrinol Metab 87: 1791-6 [PMID:11932319]

89. Misiano P, Scott BB, Scheideler MA and Garnier M. (2003) PTH2 receptor-mediated inhibitory effect of parathyroid hormone and TIP39 on cell proliferation. Eur J Pharmacol 468: 159-66 [PMID:12754053]

90. Murray TM, Rao LG, Divieti P and Bringhurst FR. (2005) Parathyroid hormone secretion and action: evidence for discrete receptors for the carboxyl-terminal region and related biological actions of carboxyl- terminal ligands. Endocr Rev 26: 78-113 [PMID:15689574]

91. Nutt RF, Caulfield MP, Levy JJ, Gibbons SW, Rosenblatt M and McKee RL. (1990) Removal of partial agonism from parathyroid hormone (PTH)-related protein-(7-34)NH2 by substitution of PTH amino acids at positions 10 and 11. Endocrinology 127: 491-3 [PMID:2163325]

92. Offermanns S, Iida-Klein A, Segre GV and Simon MI. (1996) G alpha q family members couple parathyroid hormone (PTH)/PTH-related peptide and calcitonin receptors to phospholipase C in COS-7 cells. Mol Endocrinol 10: 566-74 [PMID:8732687]

93. Okazaki M, Ferrandon S, Vilardaga JP, Bouxsein ML, Potts JT and Gardella TJ. (2008) Prolonged signaling at the parathyroid hormone receptor by peptide ligands targeted to a specific receptor conformation. Proc Natl Acad Sci USA 105: 16525-30 [PMID:18946036]

94. Philbrick WM, Wysolmerski JJ, Galbraith S, Holt E, Orloff JJ, Yang KH, Vasavada RC, Weir EC, Broadus AE and Stewart AF. (1996) Defining the roles of parathyroid hormone-related protein in normal physiology. Physiol Rev 76: 127-73 [PMID:8592727]

95. Pines M, Fukayama S, Costas K, Meurer E, Goldsmith PK, Xu X, Muallem S, Behar V, Chorev M and Rosenblatt $\mathrm{M}$ et al.. (1996) Inositol 1-,4-,5-trisphosphate-dependent Ca2+ signaling by the recombinant human PTH/PTHrP receptor stably expressed in a human kidney cell line. Bone 18: 381-9 [PMID:8726398]

96. Pioszak AA and Xu HE. (2008) Molecular recognition of parathyroid hormone by its G proteincoupled receptor. Proc Natl Acad Sci USA 105: 5034-9 [PMID:18375760]

97. Piserchio A, Usdin T and Mierke DF. (2000) Structure of tuberoinfundibular peptide of 39 residues. J Biol Chem 275: 27284-90 [PMID:10856302]

98. Plati J, Tsomaia N, Piserchio A and Mierke DF. (2007) Structural features of parathyroid hormone receptor coupled to Galpha(s)-protein. Biophys J 92: 535-40 [PMID:17040990]

99. Potts JT Jr, Bringhurst FR, Gardella T, Nussbaum S, Segre G and Kronenberg H. (1995) Parathyroid hormone: physiology, chemistry, biosynthesis, secretion, metabolism and mode of action. In William's Textbook of Endocrinology Edited by Williams RH, Wilson JD, Foster DN: Saunders: 920-966 [ISBN: 0721642640]

100. Rozeman LB, Sangiorgi L, Briaire-de Bruijn IH, Mainil-Varlet P, Bertoni F, Cleton-Jansen AM, Hogendoorn PC and Bovée JV. (2004) Enchondromatosis (Ollier disease, Maffucci syndrome) is not caused by the PTHR1 mutation p.R150C. Hum Mutat 24: 466-73 [PMID:15523647]

101. Rubin MR and Bilezikian JP. (2005) Parathyroid hormone as an anabolic skeletal therapy. Drugs 65: 2481-98 [PMID:16296873]

102. Rölz C, Pellegrini M and Mierke DF. (1999) Molecular characterization of the receptor-ligand complex for parathyroid hormone. Biochemistry 38: 6397-405 [PMID:10350457]

103. Schipani E, Jensen GS, Pincus J, Nissenson RA, Gardella TJ and Jüppner H. (1997) Constitutive activation of the cyclic adenosine $3^{\prime}, 5^{\prime}$-monophosphate signaling pathway by parathyroid hormone (PTH)/PTH-related peptide receptors mutated at the two loci for Jansen's metaphyseal 
chondrodysplasia. Mol Endocrinol 11: 851-8 [PMID:9178745]

104. Schipani E, Karga H, Karaplis AC, Potts Jr JT, Kronenberg HM, Segre GV, Abou-Samra AB and Jüppner H. (1993) Identical complementary deoxyribonucleic acids encode a human renal and bone parathyroid hormone (PTH)/PTH-related peptide receptor. Endocrinology 132: 2157-65 [PMID:8386612]

105. Schipani E, Kruse K and Jüppner H. (1995) A constitutively active mutant PTH-PTHrP receptor in Jansen-type metaphyseal chondrodysplasia. Science 268: 98-100 [PMID:7701349]

106. Schipani E, Langman C, Hunzelman J, Le Merrer M, Loke KY, Dillon MJ, Silve C and Jüppner H. (1999) A novel parathyroid hormone (PTH)/PTH-related peptide receptor mutation in Jansen's metaphyseal chondrodysplasia. J Clin Endocrinol Metab 84: 3052-7 [PMID:10487664]

107. Schipani E, Langman CB, Parfitt AM, Jensen GS, Kikuchi S, Kooh SW, Cole WG and Jüppner H. (1996) Constitutively activated receptors for parathyroid hormone and parathyroid hormonerelated peptide in Jansen's metaphyseal chondrodysplasia. $N$ Engl J Med 335: 708-14 [PMID:8703170]

108. Schneider H, Feyen JH and Seuwen K. (1994) A C-terminally truncated human parathyroid hormone receptor is functional and activates multiple G proteins. FEBS Lett 351: 281-5 [PMID:8082781]

109. Schneider H, Feyen JH, Seuwen K and Movva NR. (1993) Cloning and functional expression of a human parathyroid hormone receptor. Eur J Pharmacol 246: 149-55 [PMID:8397094]

110. Schwindinger WF, Fredericks J, Watkins L, Robinson H, Bathon JM, Pines M, Suva LJ and Levine MA. (1998) Coupling of the PTH/PTHrP receptor to multiple G-proteins. Direct demonstration of receptor activation of $\mathrm{Gs}, \mathrm{Gq} / 11$, and $\mathrm{Gi}(1)$ by [alpha-32P]GTP-gamma-azidoanilide photoaffinity labeling. Endocrine 8: 201-9 [PMID:9704578]

111. Scillitani A, Jang C, Wong BY, Hendy GN and Cole DE. (2006) A functional polymorphism in the PTHR1 promoter region is associated with adult height and BMD measured at the femoral neck in a large cohort of young caucasian women. Hum Genet 119: 416-21 [PMID:16508749]

112. Segre GV, Rosenblatt M, Tully 3rd GL, Laugharn J, Reit B and Potts Jr JT. (1985) Evaluation of an in vitro parathyroid hormone antagonist in vivo in dogs. Endocrinology 116: 1024-9 [PMID:2982567]

113. Seuwen K and Boddeke HG. (1995) Heparin-insensitive calcium release from intracellular stores triggered by the recombinant human parathyroid hormone receptor. Br J Pharmacol 114: 16131620 [PMID:7599930]

114. Shimizu M, Carter PH, Khatri A, Potts JT and Gardella TJ. (2001) Enhanced activity in parathyroid hormone-(1-14) and -(1-11): novel peptides for probing ligand-receptor interactions. Endocrinology 142: 3068-74 [PMID:11416029]

115. Shimizu N, Guo J and Gardella TJ. (2001) Parathyroid hormone (PTH)-(1-14) and -(1-11) analogs conformationally constrained by alpha-aminoisobutyric acid mediate full agonist responses via the juxtamembrane region of the PTH-1 receptor. J Biol Chem 276: 49003-12 [PMID:11604398]

116. Silve C and Jüppner H. (2006) Ollier disease. Orphanet J Rare Dis 1: 37 [PMID:16995932]

117. Soegiarto DW, Kiachopoulos S, Schipani E, Jüppner H, Erben RG and Lanske B. (2001) Partial rescue of PTH/PTHrP receptor knockout mice by targeted expression of the Jansen transgene. Endocrinology 142: 5303-10 [PMID:11713230]

118. Strewler GJ. (2000) The physiology of parathyroid hormone-related protein. $N$ Engl J Med 342: 177-85 [PMID:10639544]

119. Sugimura Y, Murase T, Ishizaki S, Tachikawa K, Arima H, Miura Y, Usdin TB and Oiso Y. (2003) Centrally administered tuberoinfundibular peptide of 39 residues inhibits arginine vasopressin release in conscious rats. Endocrinology 144: 2791-6 [PMID:12810532]

120. Takasu H and Bringhurst FR. (1998) Type-1 parathyroid hormone (PTH)/PTH-related peptide (PTHrP) receptors activate phospholipase $\mathrm{C}$ in response to carboxyl-truncated analogs of PTH(134). Endocrinology 139: 4293-9 [PMID:9751512]

121. Takasu H, Gardella TJ, Luck MD, Potts Jr JT and Bringhurst FR. (1999) Amino-terminal modifications of human parathyroid hormone (PTH) selectively alter phospholipase C signaling via the type 1 PTH receptor: implications for design of signal-specific PTH ligands. Biochemistry 38: 13453-60 [PMID:10521252]

122. Takasu H, Guo J and Bringhurst FR. (1999) Dual signaling and ligand selectivity of the human PTH/PTHrP receptor. J Bone Miner Res 14: 11-20 [PMID:9893061]

123. Tian J, Smogorzewski M, Kedes L and Massry SG. (1993) Parathyroid hormone-parathyroid hormone related protein receptor messenger RNA is present in many tissues besides the kidney. Am J Nephrol 13: 210-3 [PMID:8213933]

124. Turner PR, Mefford S, Bambino T and Nissenson RA. (1998) Transmembrane residues together with the amino terminus limit the response of the parathyroid hormone (PTH) 2 receptor to PTH-related peptide. J Biol Chem 273: 3830-3837 [PMID:9461563]

125. Ureña $P$, Kong XF, Abou-Samra AB, Jüppner $H$, Kronenberg HM, Potts Jr JT and Segre GV. (1993) Parathyroid hormone (PTH)/PTH-related peptide receptor messenger ribonucleic acids are widely distributed in rat tissues. Endocrinology 133: 617-23 [PMID:8393771] 
126. Usdin TB, Bonner TI, Harta G and Mezey E. (1996) Distribution of parathyroid hormone-2 receptor messenger ribonucleic acid in rat. Endocrinology 137: 4285-97 [PMID:8828488]

127. Usdin TB, Dobolyi A, Ueda H and Palkovits M. (2003) Emerging functions for tuberoinfundibular peptide of 39 residues. Trends Endocrinol Metab 14: 14-9 [PMID:12475607]

128. Usdin TB, Gruber $C$ and Bonner TI. (1995) Identification and functional expression of a receptor selectively recognizing parathyroid hormone, the PTH2 receptor. J Biol Chem 270: 15455-8 [PMID:7797535]

129. Usdin TB, Hilton J, Vertesi T, Harta G, Segre G and Mezey E. (1999) Distribution of the parathyroid hormone 2 receptor in rat: immunolocalization reveals expression by several endocrine cells. Endocrinology 140: 3363-3371 [PMID:10385434]

130. Usdin TB, Hoare SR, Wang T, Mezey E and Kowalak JA. (1999) TIP39: a new neuropeptide and PTH2-receptor agonist from hypothalamus. Nat Neurosci 2: 941-3 [PMID:10526330]

131. Usdin TB, Modi W and Bonner TI. (1996) Assignment of the human PTH2 receptor gene (PTHR2) to chromosome 2q33 by fluorescence in situ hybridization. Genomics 37: 140-1 [PMID:8921382]

132. Usdin TB, Wang T, Hoare SR, Mezey E and Palkovits M. (2000) New members of the parathyroid hormone/parathyroid hormone receptor family: the parathyroid hormone 2 receptor and tuberoinfundibular peptide of 39 residues. Front Neuroendocrinol 21: 349-83 [PMID:11013069]

133. Vilardaga JP, Gardella TJ, Wehbi VL and Feinstein TN. (2012) Non-canonical signaling of the PTH receptor. Trends Pharmacol Sci 33: 423-31 [PMID:22709554]

134. Vilardaga JP, Jean-Alphonse FG and Gardella TJ. (2014) Endosomal generation of cAMP in GPCR signaling. Nat Chem Biol 10: 700-6 [PMID:25271346]

135. Vilardaga JP, Krasel C, Chauvin S, Bambino T, Lohse MJ and Nissenson RA. (2002) Internalization determinants of the parathyroid hormone receptor differentially regulate betaarrestin/receptor association. J Biol Chem 277: 8121-9 [PMID:11726668]

136. Vilardaga JP, Romero G, Friedman PA and Gardella TJ. (2011) Molecular basis of parathyroid hormone receptor signaling and trafficking: a family B GPCR paradigm. Cell Mol Life Sci 68: 113 [PMID:20703892]

137. Wang B, Ardura JA, Romero G, Yang Y, Hall RA and Friedman PA. (2010) Na/H exchanger regulatory factors control parathyroid hormone receptor signaling by facilitating differential activation of G(alpha) protein subunits. J Biol Chem 285: 26976-86 [PMID:20562104]

138. Wang T, Palkovits M, Rusnak M, Mezey E and Usdin TB. (2000) Distribution of parathyroid hormone-2 receptor-like immunoreactivity and messenger RNA in the rat nervous system. Neuroscience 100: 629-49 [PMID:11098126]

139. Ward HL, Small CJ, Murphy KG, Kennedy AR, Ghatei MA and Bloom SR. (2001) The actions of tuberoinfundibular peptide on the hypothalamo-pituitary axes. Endocrinology 142: 3451-6 [PMID:11459790]

140. Watson PH, Fraher LJ, Hendy GN, Chung UI, Kisiel M, Natale BV and Hodsman AB. (2000) Nuclear localization of the type $1 \mathrm{PTH} / \mathrm{PTHrP}$ receptor in rat tissues. J Bone Miner Res 15: 1033-44 [PMID:10841172]

141. Watson PH, Fraher LJ, Kisiel M, DeSousa D, Hendy G and Hodsman AB. (1999) Enhanced osteoblast development after continuous infusion of $\mathrm{hPTH}(1-84)$ in the rat. Bone 24: 89-94 [PMID:9951775]

142. Wehbi VL, Stevenson HP, Feinstein TN, Calero G, Romero G and Vilardaga JP. (2013) Noncanonical GPCR signaling arising from a PTH receptor-arrestin-GßY complex. Proc Natl Acad Sci USA 110: 1530-5 [PMID:23297229]

143. Yamaguchi T, Hosomichi K, Narita A, Shirota T, Tomoyasu Y, Maki K and Inoue I. (2011) Exome resequencing combined with linkage analysis identifies novel PTH1R variants in primary failure of tooth eruption in Japanese. J Bone Miner Res 26: 1655-61 [PMID:21404329]

144. Yang T, Hassan S, Huang YG, Smart AM, Briggs JP and Schnermann JB. (1997) Expression of $\mathrm{PTHrP}, \mathrm{PTH} / \mathrm{PTHrP}$ receptor, and $\mathrm{Ca}(2+)$-sensing receptor mRNAs along the rat nephron. $\mathrm{Am} \mathrm{J}$ Physiol 272: F751-8 [PMID:9227636]

145. Zhang P, Jobert AS, Couvineau A and Silve C. (1998) A homozygous inactivating mutation in the parathyroid hormone/parathyroid hormone-related peptide receptor causing Blomstrand chondrodysplasia. J Clin Endocrinol Metab 83: 3365-8 [PMID:9745456]

146. Zhang YY, Liu PY, Lu Y, Xiao P, Liu YJ, Long JR, Shen H, Zhao LJ, Elze L and Recker RR et al.. (2006) Tests of linkage and association of PTH/PTHrP receptor type 1 gene with bone mineral density and height in Caucasians. J Bone Miner Metab 24: 36-41 [PMID:16369896]

147. Zhao LH, Ma S, Sutkeviciute I, Shen DD, Zhou XE, de Waal PW, Li CY, Kang Y, Clark LJ and Jean-Alphonse FG et al.. (2019) Structure and dynamics of the active human parathyroid hormone receptor-1. Science 364: 148-153 [PMID:30975883] 